\author{
Katarzyna Maliszewska \\ ORCID 0000-0003-0636-8570
}

\title{
KOBIETY W SYTUACJI KRYTYCZNEJ - ADULT FLOATING NA SCENIE (ANDRAGOGICZNE WĄTKI W EDUKACJI TEATRALNEJ)
}

\begin{abstract}
Slowa kluczowe: teatr studencki, edukacja dorosłych, biografia, zawieszenie w dorosłości, tożsamość.

Streszczenie: Artykuł został oparty na doświadczeniach pracy teatralnej w amatorskim teatrze studenckim. Refleksje dotyczące doświadczeń pedagogicznych z młodym dorosłym zostały skonstruowane na podstawie kategorii zawieszenia w dorosłości (floating). Uczestnictwo w kulturze poprzez aktywne działanie w studenckim teatrze to jedna $\mathrm{z}$ form edukacji dorosłych. Budowanie scenicznej postaci, współpraca z drugim człowiekiem, nauka podstaw aktorskiego rzemiosła to ważne doświadczenie biograficzne o egzystencjalnym i rozwojowym charakterze.
\end{abstract}

Życie każdego czlowieka jest droga ku samemu sobie, próba znalezienia drogi, zaznaczenia ścieżki.

Żaden czlowiek nie byt nigdy w petni samym soba, lecz mimo to każdy ku temu dąży, jeden w mroku, inny w świattości, jak kto umie [...].

Możemy zrozumieć się nawzajem; lecz wyjaśnić samego siebie każdy może

tylko sam

(H. Hesse, Demian)

\section{Biograficzne floating - wstęp}

Współczesny człowiek zaczyna silnie odczuwać egzystencjalną niepewność, zagubienie i chaos. Zostaje wystawiony na próbę radzenia sobie z życiowym niepokojem. Otaczający go świat często przeraża, jawi się jako trudna do 
zrozumienia mozaika skomplikowanych emocji i wydarzeń. To zjawisko dotykające człowieka na każdym etapie jego życia. Niezwykle trafna wydaje mi się w tym kontekście kategoria biograficznego zawieszenia (floating), o której pisze Agnieszka Bron. To stan zagubienia, często nieumiejętność podjęcia ważnych decyzji życiowych jako konsekwencja trudności i problemów w sferze osobistej, emocjonalnej, intelektualnej i fizycznej. Opisując to zjawisko, Bron wyróżnia kilka ważnych etapów: 1) doświadczenie niepewności i niepokoju; 2) utrata bezpieczeństwa w środowisku społecznym; 3) doświadczanie i uświadomienie sobie kryzysu; 4) radzenie sobie, podjęcie decyzji i działań przeciw kryzysowi (Bron 2006, s. 21). Pod wpływem różnorodnych czynników wewnętrznych oraz zewnętrznych człowiek może zostać ,zatrzymany” w pewnym momencie swojego życia. Nie tyle jest dorosłym, ile próbuje nim być. Ludzie pozostający we floating doświadczaja bezradności, odczuwaja brak możliwości wpływania na swoje życie, poczucie fragmentaryzacji, a także często poczucie utraty tożsamości (Malec 2008, 133-134). Tego rodzaju kondycja to nieustające wyzwanie dla edukacji dorosłych, polegające na potrzebie poddawania ludzkiej egzystencji pogłębionej refleksji, koncentracji na jej odcieniach i złożonościach.

\section{Teatr jako przestrzeń doświadczania biograficznego floating}

Agnieszka Bron w rozważaniach na temat zawieszenia w dorosłości podkreśla znaczenie narracji, opowiadania historii jako najważniejszego instrumentu uczenia się biograficznego (Bron 2006, s. 19). Niezwykle pomocna w tym zakresie może stać się przestrzeń sztuki teatralnej. Twórcy spektakli często akcentują problemy współczesnej tożsamości człowieka (skądinąd w ramach innej dziedziny opisywanej w rozprawach naukowych andragogów). Aktora nobilituje uczestniczenie we wspótczesności, a widz również szuka w teatrze odpowiedzi na swoje troski i niepokoje (Hanin 2018, s. 48).

Znakomitym przykładem teatralnego zobrazowania dylematów dorosłości jest, w moim przekonaniu, sztuka Kobiety w sytuacji krytycznej autorstwa Joanny Murray-Smith, australijskiej pisarki, scenarzystki i autorki sztuk teatralnych. Miałam przyjemność reżyserować ten spektakl, pracując z młodymi dorosłymi w przestrzeni teatru studenckiego. Komentatorzy piszą o Murray-Smith: ,prawdziwa kobieta renesansu" " z kolei ona sama podkreśla, że pisanie i opowiadanie historii uratowało jej życie. To wyjątkowe wyznanie w kontekście wnikliwości, z jaką kreuje swoje bohaterki. Tekst sztuki znakomicie wpisuje się w problematykę radzenia sobie $\mathrm{z}$ własną dorosłością w nieprzychylnej rzeczywistości. To niezwykła opowieść o kobietach, które z kryzysów czynią swoją tożsamość. Każda $\mathrm{z}$ bohaterek przeżywa biograficzne floating.

\footnotetext{
https://teatrmuzyczny.torun.pl/aktualnosci/joanna-murray-smith/ [29.06.2019 r.]
} 
Młode aktorki, podejmując pracę nad sztuką, mówią o niej tak: Tekst byt z jednej strony prosty, a z drugiej skomplikowany $i$ wielotorowy. Dotyczył wielu zagadnień, problemów i sytuacji codziennych, z którymi kobiety z różnych stron świata zmagaja się i moga się zmagać. Poruszat kwestie wedtug mnie nieczęsto omawiane (Klaudia); Myślę, że tekst tego spektaklu jest wypetniony prawda, ale też na tyle dynamiczny, by wywołać w widzu różne emocje (Ola); Tekst spektaklu niesie ze sobą duże napięcie emocjonalne pod przesłona humoru. Rozśmiesza i rozbawia widza absurdalnymi zachowaniami postaci, jednak pod nimi kryja sie ludzkie dramaty (Natalia).

Sztuka Joanny Murray-Smith Kobiety w sytuacji krytycznej (w tłumaczeniu Elżbiety Woźniak) przełamuje stereotypowy obraz współczesnej kobiety, ukazując jej prawdziwe oblicze. Składa się z opowieści skoncentrowanych na przeżywaniu egzystencjalnego kryzysu. W oryginale tekstu dramatycznego poznajemy 5 kobiet. W spektaklu studenckim, który przygotowałam wraz z kołem Improteatr w 2019 roku na Wydziale Pedagogiki i Psychologii Uniwersytetu Śląskiego, pojawiło się aż 10 wyjątkowych bohaterek (przekształciłam i dostosowałam tekst na potrzeby konkretnej grupy aktorów). Kobiety mogą w każdej z nich odnaleźć siebie albo do losów bohaterek dopisać własną historię. Teatr to kontekst czegoś, co jest wiecznym szukaniem, niepokojem, wiecznym odkrywaniem? Ciagtym ryzykiem? [...] teatr to potrzeba budzenia czegoś i tworzenia na nowo, potrzeba zdobywania obszarów nieznanych. Teatr to podpowiadanie pytania i proponowanie dziesiątków odpowiedzi na nie; każda odpowiedź prawdziwa $i$ żadna niewystarczająca - pisze Zuzanna Łozińska, aktorka i reżyserka teatralna (Łozińska 2018, s. 96).
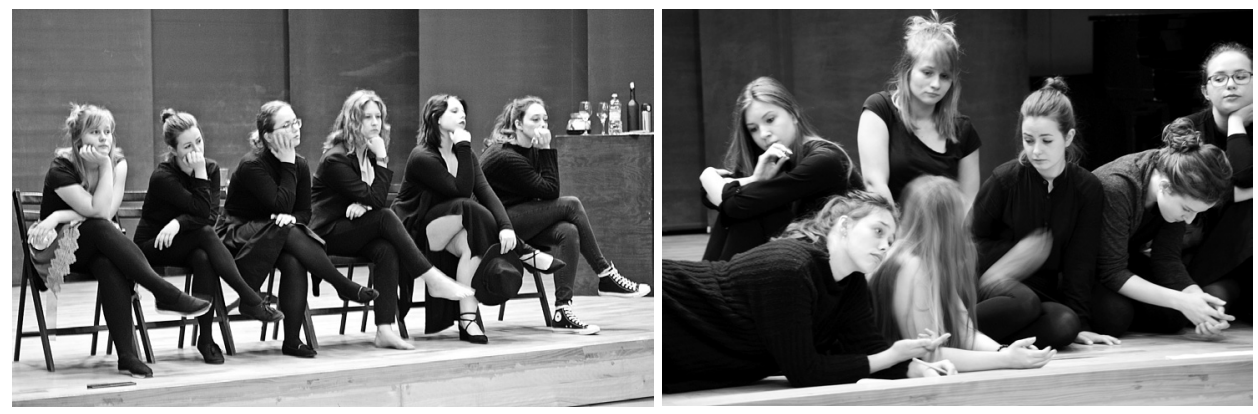

Fot. Edyta Nieduziak

\section{Kobiece kryzysy - intymne spotkanie sceniczne}

Na scenie każda intymna ludzka historia wystawiona zostaje na publiczny ogląd, przestaje być tajemnicą. Posiadanie takich właściwości przenosi teatr do centrum ponowoczesnego doświadczenia floating. 
Jedną z głównych bohaterek spektaklu jest Mira, wyczerpana młoda matka, jej tożsamością staje się rola społeczna, którą przyjęła. Wypełnia swoje zadanie z pełnym poświęceniem, wręcz mechanicznie, tracąc przy okazji poczucie własnej wartości i sens swojego działania: Budzę się... Budzik pokazuje siódma, nie szóstą. Trzeba nakarmić dziecko. Nie! Najpierw muszę się napić kawy. O, Boże, dlaczego nasze dziecko musi teraz jeść? [...] Co robię źle? Jestem egoistyczna, wiecznie głodna, nieopanowana matka. Jest rano, a ja już jestem zmęczona. [...] Z Piotrusiem coś jest nie tak. Nie lubi mnie, a ma dopiero osiem lat. Mam wrażenie, że mnie nie akceptuje. Bo na niego krzyczę. Dlaczego na niego krzyczę? Dlaczego nie mogę się kontrolować? Jestem matka, tylko tyle i aż tyle! Jestem idiotka nie matka. Jestem maniaczka, musze wszystko kontrolować! ${ }^{2}$. Postać Miry jest dobrym przykladem poczucia bezradności (pod maską impulsywnego, chaotycznego i często nieracjonalnego działania). Kobieta przeżywa konflikt ról społecznych, które wypełnia. Krytycznie balansuje na stykach bycia matką, żoną i indywidualnością - stanowiącą o sobie kobietą. Jej działania wpisuje się w I etap adult floating w ujęciu Bron, którym jest doświadczenie niepewności i niepokoju.

W opozycji do poświęcającej się życiu rodzinnemu Miry stoi Miranda - kobieta sukcesu, zimna bizneswoman. Jest pozbawiona zewnętrznych emocji, silnie skoncentrowana na osiągnięciu życiowego sukcesu. Jednak pod maską zadowolenia z siebie i sterylnie poukładanego świata chowa swoje prawdziwe oblicze - zagubionej i niespełnionej kobiety. Powoli do głosu dochodzą jej głęboko skrywane zranienia i tęsknoty. Zapada się w sobie, traci swoją tożsamość: Dlatego nie rozumiem, po co komu dzieci. Tylko płacza, brudza, gubia rzeczy. Moje życie jest idealne. Wspaniała praca, cudowny, przystojny mą̇ $i$ co najważniejsze żadnych dzieci! Ład i porządek. [...] Wtedy się dowiedziałam.... Może tak i lepiej? W końcu skoro dzieci doprowadzaja człowieka do takiego stanu to bez sensu je mieć. Nie rozumiem, jak można cieszyć się z opiekowania nimi. Poświęcać im cały czas. I dlaczego? Po co? Żeby spojrzało na ciebie, uśmiechnęło się czy nazwało mama?? To bez sensu... całkowicie bez sensu! Prawda? [...] Nigdy tego nie mówiłam, ale nie jestem szczęśliwa. Analizując postać Mirandy, mamy do czynienia z wyraźnym kryzysem tożsamości, z rozbieżnością między emocjonalnymi potrzebami kobiety a jej racjonalnymi działaniami i wyborami. Bohaterka zaczyna doświadczać biograficznej niepewności i coraz wyraźniej uświadamiać sobie swój własny kryzys (III etap adult floating).

Kolejną wyjątkową bohaterką jest Maria, panna z wyboru, nieustannie racjonalizująca swoją sytuację życiową. Jest pogodzona z rolą społeczną, którą wymogło na niej społeczeństwo. Idealnie wpisuje się w wymagane standardy $\mathrm{i}$ konwenanse. Jednak za uporządkowaną panną kryje się delikatna kobieta nieśmiało szukająca

Tekst spektaklu oparty jest na sztuce Joanny Murray-Smith, przełożonej przez Elżbietę Woźniak (której serdecznie dziękuję za udostępnienie tłumaczenia), ale został przeze mnie zmodyfikowany i uzupełniony o nieistniejące w oryginale fragmenty w procesie dostosowywania go do potrzeb konkretnych aktorek-studentek. 
prawdziwej, głębokiej relacji: Tęsknoty, jakie się odczuwa należy ukrywać, bo jest to coś... niestosownego, calkowicie nawet krepujacego dla innych. Powiedzmy sobie otwarcie - tęsknoty i marzenia u dojrzatych panien to coś - nietolerowanego. A przecież jednak każdy pragnie, żeby przydarzyło się coś niezwykłego. Każdy, my także, ale my nie mamy prawa do marzeń. A przecież teoretycznie coś może się zdarzyć samotnej, dojrzałej kobiecie. [...] Niby nie jesteś sama, sa dookoła ciebie ludzie, a jednak... to jest taki specjalny rodzaj samotności... i bezradności. Stan bez nadziei. Maria całą swoją postawą odzwierciedla jeden z głównych wymiarów doświadczenia floating, czyli nieumiejętność podjęcia ważnych decyzji życiowych jako konsekwencji problemów w sferze osobistej i emocjonalnej. Reprezentuje kryzys niespójności oczekiwań i realnych działań. Bohaterka jest tylko z pozoru pogodzona ze swoją sytuacją życiową. Dopiero w ostatnim monologu podejmuje decyzje i działania przeciw kryzysowi (To było letnie popołudnie, kiedy pierwszy raz odwiedziłam Patryka [...] Opowiadałam mu rzeczy i uczucia, o które się nie podejrzewałam albo ich nie pamiętałam), wpisując się w IV etap adult floating.

Niezwykle symptomatyczna w kontekście sytuacji młodych dorosłych jest postać Marisy, mężatki z problemami pamięci. Dziewczyna poprzez swoją przypadłość skrupulatnie notuje wszystko, co ją spotyka, balansując emocjonalnie między dzieciństwem a dorosłością, bezpieczeństwem i wolnością, zależnością i samostanowieniem: Wystarczy tylko usiąść i przypomnieć sobie, tylko przypomnieć. To nie jest takie trudne, robię to przecież każdego dnia. To jak mycie zębów albo wiązanie butów. Muszę pamiętać, żeby pamiętać. [...] Na lodówce znalazłam karteczkę z wiadomościa od mojego męża: ,, Wspominałaś, że chcesz iść dzisiaj do biblioteki poczytać i zrobić notatki. Nie zapomnij tylko drogi do domu!'”. Traktuje mnie jak dziecko. Czasami się tak ze mna droczy. Ale co dziwne, nigdy nie zapomniałam drogi do domu. Postać Marisy jest niezwykle ciekawa z punktu widzenia badań nad zjawiskiem zawieszenia $w$ dorosłości. Dziewczyna silnie odczuwa nieustanną utratę własnej tożsamości, brak możliwości wpływania na swoje życie. W konsekwencji zostaje zdominowana przez I etap adult floating, którym jest stan zagubienia i krytyczne doświadczenie egzystencjalnego niepokoju.

Kolejną bohaterką jest Małgorzata, tajemnicza, zamknięta w sobie, zraniona ważną dla siebie relacją, rozczarowana życiem. Jest przepełniona goryczą i obawą przed wchodzeniem w jakąkolwiek bliższą relację. Destruktywnie oddala się od innych, tworząc wokół siebie niewidzialny mur: Rozumiem, że można kogoś uwieść i zawieść, można się z kimś rozwieść, można kogoś porzucić, ale nie wolno go uszkadzać. Jeżeli na paczkach ze szkłem pisze się: Uwaga! Szkło, to czemu na paczce, w której mieści się nasze serce, nie miałoby być napisu: Uwaga! Drugi człowiek? [...] Duchowa strona człowieka nie podlega żadnej ochronie. To aźsmieszne: na robienie zwykłych domięśniowych zastrzyków trzeba mieć specjalne pozwolenie, ale majstrować przy duszy ludzkiej może praktycznie każdy, kto zechce: ksiadz, kochanek, przechodzień. Nikt. Małgorzata to kolejna 
bohaterka, która nie jest w stanie podjąć działań i ważnych decyzji życiowych w konsekwencji trudności i zranień w sferze osobistej, emocjonalnej i intelektualnej. Utrata bezpieczeństwa w środowisku społecznym (II etap floating) to efekt jej izolacji w otoczeniu, zamknięcia się na relacje, poczucia głębokiej samotności.

Podobne emocje przeżywa Muszka, urokliwa hodowczyni kaktusów, a jednocześnie kobieta zdradzona, usilnie szukająca akceptacji i bliskości. Ku zaskoczeniu otaczającego ją świata, znajdująca ukojenie w pielęgnacji roślin doniczkowych, niemych, ale okazujących jej wierność i zrozumienie: Moje kaktusy odegraty bardzo ważna dla mnie rolę, pomagając mi w utrzymaniu równowagi. [...] Jedna z koleżanek wzięła mnie na bok i powiedziała: Muszko, jeżeli chcesz oddać sprawiedliwość naszemu wielkiemu przyjacielowi, kaktusowi, musisz uświadomić wszystkim, jak wielkie miat znaczenie i jak duża role odegrat w twoim życiu osobistym, w przezwyciężaniu trudności, bólu i upokorzenia. [...] Moje kaktusy kochaja mnie. A ja kocham je. Tak wiele im zawdzięczam. [...] kiedy to wszystko się stało... Nie bytam sama. Czułam, że kaktusy sa moimi sprzymierzeńcami. Czy za dużo proszę! Postać Muszki symbolizuje wręcz podręcznikowy obraz egzystencjalnego kryzysu i zawieszenia $w$ dorostości. Jej emocje, zachowania i decyzje płynnie przechodzą przez wszystkie etapy adult floating - od doświadczenia niepewności, przez utratę bezpieczeństwa społecznego, uświadomienie sobie kryzysu, aż do radzenia sobie i podejmowania działań o charakterze terapeutycznym.

Zderzenie z trudną rzeczywistością to również doświadczenie kolejnej bohaterki sztuki - Marty, pełnej ideałów młodziutkiej panny młodej, realizującej właśnie, zgodnie z planem, swoje nastoletnie marzenie o białej sukience. Jest niedojrzała i całkowicie niegotowa do podejmowania ważnych decyzji życiowych. Przechodzi od gwałtownego podekscytowania i egzaltacji do dziecięcego, paraliżującego lęku o przyszłość: Przyjrzyjcie się przez chwile pannie młodej! Stoi na krawędzi między światem marzeń a światem spetnienia się. U progu zmiany $z$ dziewczyny w kobietę, z ,ja” do ,my”. Super! [...] Będę czyjąś żona. Kogoś. Kogokolwiek. Żona. Żonka, żoneczka, żonusia. Dziwne stowo ,'żona”. Nigdy wcześniej o tym nie myślałam. Brzmi jak... urzadzenie kuchenne. Chodzi o to, że będe należała do kogoś. Jak będzie wygladało moje życie? [...] Co on mówit? Co on wtedy mówit? „,Obiecuję, że będę się toba opiekowat jak małym drzewkiem, rosnacym obok wielkiej rzeki miłości? Obiecuję podlewać cię i chronić przed stońcem. Pozwolić ci wyrosnać na... duże, mocne drzewo". Że co? [...] Co ja zrobiłam? Ja tylko chciałam założyć sukienkę... Marta to młodziutka dziewczyna, która nie tyle jest dorosła, co próbuje się nią stawać. Przeżywa klasyczny kryzys dojrzewania. Jej brak dojrzałości emocjonalnej skutkuje silnym poczuciem zagubienia, chaosu i lęku egzystencjalnego (I etap adult floating). Nie jest gotowa na podjęcie ważnych dla siebie decyzji życiowych, coraz bardziej pogrąża się w niepewności co do swojego przyszłego życia, wybranej roli społecznej i konsekwencji z nią związanych. 
Jej wątpliwościom przygląda się Marianna, kobieta po przejściach, artystka, której kariera dawno zgasła - walcząca z nałogami, samotnością i demonami przeszłości. Słucha opowieści swoich scenicznych koleżanek z dystansem, próbując odbudować w sobie motywację, aby mimo trudności zawalczyć o siebie i swoje życie: Będę z wami szczera... Piłam. Piłam przed śniadaniem, do obiadu, na sen. Wszyscy pili... Były takie momenty, że... nie wiedziałam, kim jestem. Czułam się jak gówno... Ale nie tak łatwo umrzeć. Byto we mnie cholernie dużo życia! Chciałam powiedzieć, że na przekór wszystkiemu, na przekór sobie wrócitam! [...] W tym samym roku, w którym spalit się mój dom, w którym wszystko się spalito, moja matka zachorowała i pojechałam, żeby się z nia zobaczyć, a być może pożegnać. Pojechałam pijana. Zanim zamknęta oczy, po raz ostatni uścisnęła mi rękę, westchnęta i powiedziała, że mnie kocha. Załamałam się. [...] Pewnego dnia pomyślałam: albo zdechnę, albo wyjdę z tego i przestanę się nad sobq użalać... zaczęlam walczyć...

Marianna (podobnie jak wcześniej wspomniana Muszka) przeżywa wachlarz rozmaitych kryzysów (m.in. twórczy, małżeński, macierzyński, związany z uwikłaniem w nałogi i stany depresyjne), emocji i doświadczeń życiowych. Przechodzi przez wszystkie etapy biograficznego floating. W finale sama mówi: Wygrałam i próbuję być szczęśliwa. Jej postać daje nadzieję, pokazuje, że, mimo największych trudności, rozwojowe przejście kryzysów i osiągnięcie dojrzałej osobowości jest możliwe.

Ostatnimi bohaterkami są z pozoru całkowicie odmienne Michalina i Miki. Pierwsza to nieśmiała, zalękniona kelnerka, zawsze stojąca w cieniu. Jest zanurzona w romantycznych marzeniach i wyobrażeniach o tym, jak mogłoby wyglądać jej życie, gdyby tylko znalazła w sobie odwagę na zmianę: Imię: Michalina... chociaż częściej: Przynieś, Zanieś, Umyj, Sprzatnij, Zrób, Zostaw... Zawód: zawodów miałam wiele... jednak najlepiej mi wychodzi bycie ofiara losu ... co tu dużo mówić... jestem jak piątek trzynastego... punkt o trzynastej. Plan na najbliższy rok: może zakochać się? Tylko jak...? Jej przeciwieństwem jest Miki, artystka, tancerka, bojąca się nużącej stabilizacji. Jest jak ptak pragnący nieskrępowanej wolności. Nie potrafi znaleźć dla siebie miejsca w społeczeństwie, nie chce wchodzić w utarte role, a jednocześnie czuje się nieakceptowana przez najbliższe otoczenie: Powinnam iść na studia, powinnam iść do pracy, ciagle coś powinnam. Wszyscy zmuszaja mnie do bycia dojrzała i odpowiedzialna, bo przecież muszę zapewnić sobie przysztość. Taniec to dziecinna zabawa. Glupie obroty tak, tak mówia moi rodzice... Nigdy nie zobaczyli do końca występu, nigdy nie pochwalili... Obie kobiety - Michalina i Miki balansują między emocjonalnością a racjonalnością przy dokonywanych wyborach życiowych. Są do siebie bardzo podobne, przeżywają pierwsze dwa etapy adult floating. Ich działanie przepełnia niespójność oczekiwań i realnych działań, rozczarowanie wymaganiami społecznymi i szeroko pojętą dorosłością.

Historie wszystkich bohaterek wpisują się w kategorię biograficznego zawieszenia, o której pisze Agnieszka Bron - w doświadczenie niepewności i niepokoju, 
środowiskową utratę bezpieczeństwa, uświadamianie sytuacji kryzysowej i próby radzenia sobie z nią. W przeżywanych przez nie kryzysach można wyraźnie zauważyć różne aspekty adult floating - to kobiety przeżywające bezradność, chaos i wątpliwości, dotknięte niespójnością własnych oczekiwań i realnie podejmowanych działań, samotnością i poczuciem braku możliwości wpływania na swoje życie, innymi słowy - kobiety zagubione, zawieszone...

\section{Transgresja i katharsis - teatralna edukacja egzystencjalna}

W mojej praktyce pedagogicznej rozważania dotyczące edukacji młodego dorosłego oraz jego kondycji we współczesnym świecie krzyżują się z doświadczeniami teatralnymi. Kategoria edukacji jest pojęciem niezwykle szerokim, obejmuje bowiem całość procesów wpływających na wielostronne i harmonijne kształtowanie się człowieka. Jak pisze Zbigniew Kwieciński: Edukacja to ogół czynności prowadzenia drugiego człowieka i jego własnej aktywności w osiaganiu petnych i swoistych dlań możliwości, jak i ogót wpływów i funkcji ustanawiajacych i regulujacych osobowość człowieka i jego zachowanie w relacji do innych ludzi $i$ wobec świata (Kwieciński, 1995, s. 14 ). Z kolei w myśli Hermana Hessego znajdujemy wątek o ważnym edukacyjnym zadaniu kształtowania człowieka twórczego, przebudzonego, takiego, który szuka drogi do siebie (por. Orzelska, 2014, s. 19). Dzisiejszy teatr może stanowić jedną z takich właśnie dróg, ponieważ widzi swoje społeczne zadanie w ukazaniu w jak najpełniejszy sposób różnorodności i zmienności ludzkiego losu. Na scenie zmaganie się z rolą i poprzez to z własną biografią konfrontuje człowieka z innością, sytuacjami granicznymi, stawia jednostkę przed newralgicznymi wyborami. Zuzanna Łozińska tak pisze o momencie wejścia w rolę: [...] trzeba wczuć się w postać, wyobrazić ją sobie, zrozumieć ją. Dlatego tak ogromne możliwości stoja przed aktorem, który potrafi czuć $i$ widzieć [...] innego człowieka, poznać jego dzieje i jego wnętrze [...]. Taka wizję bohaterki w sobie tworze i nagle ja widze przed soba [...]. I potem jakbym wchtaniała ja w siebie, ona musi być we mnie, staję się nia (Łozińska 2018, s. 99). Teatr to miejsce granic i transgresji - pokazuje momenty kryzysu w przeżywaniu własnej egzystencji. Przestrzeń teatralna pomaga postrzegać ów kryzys w kategoriach rozwojowych.

Nie zawsze chodzi o tragiczne doświadczenia życiowe, niejednokrotnie substancją pracy teatralnej stają się codzienne emocje, mikrodecyzje, które w przestrzeni sceny nabierają nowego wymiaru. Według Zbigniewa Zapasiewicza, teatralna głębia łączy w sobie wszystkie odsłony ludzkich zachowań. Umiejętnie połączone tworzą prawdziwą historię każdego człowieka (Zapasiewicz 2007, 195). To niekończący się projekt biograficzny, który w wyjątkowy sposób można realizować w przestrzeni sztuki teatralnej. Monika Jaworska-Witkowska w książce Ku kulturowej koncepcji pedagogiki wskazuje na dwa podejścia do kultury - funkcjonalne, polegające na kontakcie z różnymi dziedzinami kultury i działaniach (wy)twórczych służących nabywaniu rozmaitych umiejętności oraz strukturalne, 
które nawiązuje do tego, co Wincenty Okoń nazywa „dydaktyką przeżycia” koncentracją na otwieraniu się na ważne impulsy, na zdolności do przejmowania się kontaktem kulturowym, na przebudzaniu się za jego pomocą i dokonywaniu tożsamościowych zmian (Jaworska-Witkowska 2009, s. 56-58). W tym kontekście teatr staje się niezwykłą formą edukacji młodych dorosłych, bo pozwala na „schodzenie w głąb" - strukturalne, a nie tylko funkcjonalne podejście do biograficznych narracji i kryzysów.

Praca z młodym dorosłym w teatrze to wyjątkowe przedsięwzięcie. Dla mnie jako pedagożki i jednocześnie reżyserki spektakli studenckich to niezwykle trudne emocjonalnie doświadczenie, bezpośrednio nawiązujące do „dydaktyki przeżycia” Okonia. W przestrzeni tekstu dramatycznego, nad którym pracowaliśmy wiele miesięcy, kryzysy scenicznych bohaterek zaczęly splatać się z kryzysami młodych aktorek. Studentki wprowadziły w kreacje aktorskie siebie, własne emocje, skojarzenia i biograficzne epizody, w niezwykły sposób ucieleśniając opowiadane historie. Jedna z nich mówi tak: Gdy dostałam po raz pierwszy scenariusz, myślałam, że moja postać będzie łatwa. Praktycznie każdy mi mówit, że to jest czastka mnie. Ale $z$ każda próba czułam, że zaczyna mnie to przerastać, że emocje odczuwane przez Mariannę sa za silne, za dojrzate lub za ,ciężkie”, bym nie utonęła w nich. Bałam się czasem, że gdy poczuje je za mocno, to nie zostana one na próbie, tylko stana się moimi własnymi. Moja bohaterka przė̇yła wiele, więc utożsamiałam się z nia, ale dopiero na scenie miatam odwagę poczuć to, co ona przekazuje. Proces prób nie byt prosty, byt cholernie wymagajacy dla mojej psychiki. Ale to, co osiagnętam, oczyściło mnie (Ola). Inna aktorka wyznaje: Mam niewielkie doświadczenie, jeżeli chodzi o występowanie przed publicznościa, co wiąże się z tym, że gra w tego typu sztuce jest dla mnie nowościa. Występ byt dla mnie ogromnym stresem, wywołaniem i ujawnieniem swoich najskrytszych uczuć, poruszeniem wewnętrznie tego, czego gdzieś dotychczas chyba wolatam nie dotykać (Klaudia).

Praca nad spektaklem przemienia zwykłą salę wykładową w laboratorium, w którym realia życia mogą zostać bezpośrednio z sobą skonfrontowane, ujawnione, poddane eksperymentowi i próbie. Wspólna praca, długie godziny spędzone na poglębionej analizie emocji poszczególnych bohaterek to niezwykle rozwojowa przestrzeń. Natalia mówi: Budowanie postaci samo w sobie niosło duże trudności $w$ zwiazku z emocjami, jakie niosła w sobie moja postać. Wczucie się w historię od poczatku silnie oddziaływato na mnie sama. Jednak wspótpraca przy tworzeniu własnej wizji poszczególnych postaci i patrzenia, jak każdy staje się coraz lepszy, byto wyjątkowa motywacja.

Pracy teatralnej towarzyszy silnie napięcie edukacyjne. Budowanie postaci, nauka podstaw aktorskiego rzemiosła to czynności wymagające ogromnej cierpliwości i determinacji. Asia zauważyła: Kreowanie postaci było dla mnie niezapomnianym doświadczeniem i bardzo dużym wyzwaniem. Potrzebowałam wielu prób, podpowiedzi, wsparcia $i$ w efekcie udało mi się wykreować (albo Nam) zabawna, 
ale nie komiczna, lekko przerysowana, ale nie groteskowa Muszkę, o która od poczatku chodziło.

Obcowanie ze sztuką ma szansę przekształcić się w prawdziwe uczestnictwo w kulturze, o którym pisała Jaworska-Witkowska. Fenomen teatralnego współuczestnictwa polega na tym, że odbiorca tekstu dramatycznego, przetwarzając go w swej świadomości, staje się jego nowym twórcą (por. Hausbrandt 1983, s. 86). Moment wchłonięcia scenicznej rzeczywistości wiąże się ściśle z oczyszczającą rolą teatru, która stanowi od wieków jedną z najważniejszych jego funkcji (katharsis). Wyzwanie utożsamienia się z fikcyjnym bohaterem, możliwość przeżywania jego problemów, wypełnia w człowieku emocjonalną pustkę, stłumioną w codziennym życiu. Bardzo często zaspokaja głód niedostępnych doświadczeń, przeżyć oraz stanów. Ola: Występ w tym spektaklu byt bardzo emocjonujacy, bardzo rozwijający, ale też bardzo trudny dla mnie. Musiałam odnaleźć $w$ sobie osobę z trudnymi przeżyciami, osobę uzależniona, osobę bez emocji, a jednocześnie ich petna. Bardzo oczyszczajacy byt dla mnie ten spektakl, uważam, ze byt dla mnie jak terapia. W momencie, gdy stanęlam na scenie, te emocje nie pochodzity tylko od mojej bohaterki, to byty moje emocje, może nie do końca zagrane. Powiedziałabym, że emocje byty autentyczne, dokładnie czułam je w całym moim ciele. Moment, w którym czułam płacz, byt jak katharsis.

Peter Brook, jeden z najważniejszych twórców teatralnych XX wieku, pisał, że scena jest zawsze przestrzenią pustą, jest miejscem permanentnego rozpoczynania, kreacji i przebudzenia. Asia tak mówi o tym doświadczeniu: $W$ momencie wyjścia na deski zapomniałam o otaczajacym mnie świecie i o sobie, bytam swoja postacia, myślałam tylko o swoim ukochanym kaktusie i o mężczyźnie, który złamat mi serce. Poczułam naturalna więź z reszta postaci i czułam sie jakbym była $w$ alternatywnej rzeczywistości, kimś kompletnie innym. To świetne uczucie wyjścia jakby po za siebie i stworzenia czegoś kompletnie nowego. Efekt przebudzenia w pracy teatralnej wymaga zaangażowania - wejścia, a nawet pogrążenia się w fikcyjnej rzeczywistości.

W doświadczeniach aktorek-studentek doszło do głosu kilka istotnych elementów, które mogą zostać uznane za momenty procesu edukacyjnego przebudzenia ${ }^{3}$ : splot losów postaci z losami aktorów (przefiltrowywanie treści sztuki przez osobiste doświadczenia), pogłębiona analiza emocji (dokonywanie pracy emocjonalnej, por. Przybylska, 2018), napięcie edukacyjne związane z wymogiem cierpliwości i determinacji, pogrążenie w fikcyjnej rzeczywistości (przejście do innego świata). Rezultatem przejścia przez takie doświadczenia w procesie teatralnego przepracowywania kryzysów adult floating może być nawet efekt terapeutyczny realizacji spektaklu - swego rodzaju katharsis.

3 O procesie przebudzenia ciekawie piszą Monika Jaworska i Lech Witkowski (2007) w książce Przeżycie - Przebudzenie - Przemiana: inicjacyjne dynamizmy egzystencjalne w prozie Hermanna Hessego, Bydgoszcz/Kraków/Szczecin: WSH TWP, UKW, UJ. 


\section{Prawda opowieści - zakończenie}

Teatr jako jedna $\mathrm{z}$ form edukacji dorosłych ma niezwykle silne oddziaływanie. Niestety, aktywnie działające teatry studenckie w sprzyjających warunkach akademickich należą dzisiaj do rzadkości. Zdarzają się twórcze wyspy, które przywracają wiarę w rozwojową moc kultury studenckiej, ale rzeczywistość akademickiej pustyni kulturalnej staje się coraz bardziej powszechna i dojmująca. Nie znaczy to, że umarły potrzeby związane ze sceną albo że nie da się ich rozbudzić. Nie znaczy to także, że studencki teatr musi być banalny. Tak pisał w swoim Manifeście teatru meta-codziennego w 1980 Helmut Kajzar: Styszę z głośnika: teatr umart, szukamy zapomnianych źródet. Dziewczyna parska śmiechem: Teatr jest $w$ każdym moim paznokciu, ja tryskam teatrem, jestem jego nieśmiertelnym źródtem, mówi. Niosę przed soba teatr miłości, pułapkę życia, teatr skóry, kości, biżuterii, oczu (Kajzar 2007, s. 80). Dobrze pojęta praca teatralna pomaga doświadczyć studentom-aktorom nie tyle samej obecności sztuki i pracy z drugim człowiekiem (teatru funkcjonalnego), ile twórczej obecności (teatru strukturalnego). Uczy widzenia świata, prawdy słowa, gestu i działania, uczy, że najważniejsze jest przeżycie i waga opowieści.

\section{Bibliografia}

1. Bauman, Z. (1998). O miejscu teatru w ponowoczesnej sztuce. W: J. Tyszka. Teatr w miejscach nieteatralnych (red.). Poznań: Wydawnictwo Fundacji Humaniora.

2. Bron, A. (2006). Rozumienie uczenia się w teoriach andragogicznych. Teraźniejszość - Człowiek - Edukacja, nr 4 (36).

3. Hanin, R. (2018). W: J. Krakowska. (Nie)świadomość teatru (red.). Warszawa: Instytut Teatralny im. Zbigniewa Raszewskiego.

4. Hausbrandt, A. (1983). Teatr w społeczeństwie. Warszawa: Wydawnictwo Szkolne i Pedagogiczne.

5. Januszkiewicz, M. (2012). Kim jestem ja, kim jesteś ty? Etyka, tożsamość, rozumienie. Poznań: Wydawnictwo Poznańskie.

6. Jaworska, M., Witkowski, L. (2007). Przeżycie - Przebudzenie-Przemiana: inicjacyjne dynamizmy egzystencjalne w prozie Hermanna Hessego, Bydgoszcz/Kraków/ Szczecin: WSH TWP, UKW, UJ.

7. Jaworska-Witkowska, M. (2009). Ku kulturowej koncepcji pedagogiki. Kraków: Wydawnictwo Impuls.

8. Kajzar, H. (2007). Manifest teatru meta-codziennego W: W. Dudzik Świadomość teatru. Polska myśl teatralna drugiej połowy XX wieku (red.). Warszawa: Wydawnictwo Naukowe PWN.

9. Kwiecińki, Z. (1995). Socjopatologia edukacji. Olecko: Mazurska Wszechnica Nauczycielska.

10. Łozińska, Z. (2018). Grać, czyli żyć W: J. Krakowska. (Nie)świadomość teatru (red.). Warszawa: Instytut Teatralny im. Zbigniewa Raszewskiego.

11. Malec, M. (2008). Biograficzne uczenie się osób z nabytym stygmatem. Wrocław: Oficyna Wydawnicza ATUT. 
12. Orzelska, J. (2014). W stronę pedagogiki istotnej egzystencjalnie. Kraków: Wydawnictwo Impuls.

13. Przybylska, I. (2018). Dyskursy o emocjach - pedagogika i codzienność szkolna. Katowice: Wydawnictwo Uniwersytetu Śląskiego.

14. Zapasiewicz, Z. (2007). Stowo w działaniu aktora. W: W. Dudzik Świadomość teatru. Polska myśl teatralna drugiej połowy XX wieku (red.). Warszawa: Wydawnictwo Naukowe PWN.

15. https://teatrmuzyczny.torun.pl/aktualnosci/joanna-murray-smith/ [29.06.2019 r.]

\section{WOMEN IN A CRITICAL SITUATION - 'ADULT FLOATING' ON THE THEATRE STAGE (ANDRAGOGICAL THREADS IN THEATER EDUCATION)}

Keywords: student theater, adult education, biography, floating in adulthood, identity.

Summary: The article is based on the experience of theatrical work in the amateur student theater. Reflections on pedagogical experience with young adults have been constructed on the basis of notion of ,floating' referring to adulthood. Participation in culture through active action in the student theater is one of the forms of adult education. Building a stage character, working with another person, learning the basics of acting craft are important biographical experiences of an existential and development character.

Dane do korespondencji:

\section{Mgr Katarzyna Maliszewska}

Uniwersytet Śląski w Katowicach

Instytut Pedagogiki

ul. Grażyńskiego 53

e-mail: katarzyna.maliszewska.us@gmail.com 